\title{
Construction Of Student's Political Rights About Sexy Killers Showing
}

\author{
Fatmawati $^{1)}$, Siti Maizul Habibah ${ }^{2)}$ \\ Pancasila and Citizenship Education Study Program, Faculty of Social Sciences and Law, State \\ University of Surabaya, Indonesia ${ }^{1,2}$ \\ fatmawatimatsiri@gmail.com
}

\begin{abstract}
The purpose of this study was to describe the impact of the presentation of Sexy Killers on the Political Rights of Students of the Faculty of Social Sciences and Law at the State University of Surabaya. The screening of the Sexy Killers film through social media has an impact on the political rights of students where the political rights of these students will determine the political choices made by students. The political choices of students themselves are influenced by the political views of students regarding the Sexy Killers film and the political attitudes of students by giving or not giving voting rights during the 2019 presidential election as a result of the Sexy Killers film. The focus in this research is student suffrage. The method used is a qualitative approach with a case study design. The result of this research is that there is an impact of changing students 'perspectives on politics and students' perspectives on their political choices as a result of the screening of the Sexy Killers film, although many students are pessimistic and disappointed with their political choices so that students choose what is considered good in terms of achievement and track record candidates so that there is also no political choice for golput, although feelings of pessimism and disappointment persist.
\end{abstract}

Keywords: Sexy Killers, students, Political suffrage

\begin{abstract}
Abstrak. Tujuan penelitian ini adalah untuk mendeskripsikan dampak penyajian Sexy Killers terhadap Hak Politik Mahasiswa Fakultas Ilmu Sosial dan Hukum Universitas Negeri Surabaya. Pemutaran film Sexy Killers melalui media sosial berdampak pada hak politik mahasiswa dimana hak politik mahasiswa tersebut akan menentukan pilihan politik yang dibuat mahasiswa. Pilihan politik mahasiswa sendiri dipengaruhi oleh pandangan politik mahasiswa terhadap film Sexy Killers dan sikap politik mahasiswa dengan memberikan atau tidak memberikan hak suara pada pemilihan presiden 2019 akibat film Sexy Killers. Fokus dalam penelitian ini adalah hak pilih siswa. Metode yang digunakan adalah pendekatan kualitatif dengan desain studi kasus. Hasil dari penelitian ini adalah terdapat dampak dari perubahan cara pandang mahasiswa terhadap politik dan cara pandang mahasiswa terhadap pilihan politiknya sebagai akibat dari pemutaran film Sexy Killers, walaupun banyak mahasiswa yang pesimis dan kecewa dengan pilihan politiknya sehingga agar mahasiswa memilih yang dinilai baik dari sisi prestasi dan rekam jejak calon sehingga juga tidak ada pilihan politik untuk golput, meski perasaan pesimis dan kecewa tetap ada.
\end{abstract}

Kata Kunci: Pembunuh Seksi, mahasiswa, Hak pilih politik 


\section{INTRODUCTION}

Indonesia is a country where the requirements for diversity, ethnic diversity, religion, race, and inter-group are the hallmarks of the Indonesian state, as a country that requires diversity, it is not uncommon for this diversity to eventually lead to some friction that occurs in society (Daradji, 2019). The friction that leads to conflicts that occur in the community is motivated by various reasons, one of which is due to differences in political views. Politics itself is an activity or attitude related to power in order to influence, change or maintain a kind of social structure (Noer, 1965).so that if politics is an activity related to power, then politics cannot be separated from humans. Politics is also interpreted as a phenomenon related to humans who always live in society because humans are basically social beings who always live dynamically and develop and politics is a symptom that manifests human beings in the context of their development process (Nambo \& Puluhuluwa, 2005).. This means that humans are social beings so that in their daily life they will carry out social interactions, so to create norms that can be obeyed and carried out by the community, the way that can be used is through politics with the existence of power because through power will produce positions and roles in a society

Politics itself in reality often presents conflict in society. One of the reasons for political conflict in society if there are at least two different interests because conflict is a logical consequence of the social construction of society which is built from different ethnic, religious and racial groups and this kind of social construction can naturally lead to differences in values. which could potentially lead to conflict (Chusnul Mar'iyah, 2020). The existence of diversity in society can of course be an indicator of conflicts that occur and the reality that occurs in today's society. differences in political views and political choices are the reasons for conflicts to occur in society. Differences in views and political choices in society according to(Arsad, Suaib and Nasir, 2018) can occur because of horizontal cultural pluralism caused by each cultural element trying to maintain its cultural identity and characteristics and vertical pluralism that focuses on wealth, knowledge, and power. So that differences in political views and differences in political choices can be based on culture, knowledge, wealth and power

Differences in political views and differences in political choices in the fulfillment of one's political rights which can result in conflicts that occur in society so that it raises questions regarding the role of society, especially students in viewing these differences, is not a difference that leads to conflict but becomes a shared identity that in the middle differences but still aims at achieving the goals and ideals of the state, especially the fulfillment of the right to be 
elected and to choose as the basis of the Indonesian legal state.

A person's political choices are influenced by several things. Externally, political choices can also be influenced by the influence of the elite where in every society there are two classes of population, namely one ruling class called the elite and one controlled, namely society. The first class or elite which is always a minority, carries out all political functions, monopolizes power, and enjoys the benefits provided by that power. While the second class, which is much larger in number, is regulated and controlled by the elite class (Haliim, 2017) .

The study of voting behavior is actually seen in a probabilistic approach, not deterministic, because all factors can have an effect. So, what is seen in terms of factor proportionality, how much is the dominant factor and is able to better explain political choices (Haryanto, 2014) . This means that a person's political choices are actually much influenced by these human factors in explaining their politics well, the explanation can be based on religion, social class, ethnicity, region, family traditions and others as sociological values.

In political concepts related to power, the election of candidate leaders becomes a relevant matter. Indonesia, which adheres to a presidential system, of course implements general elections every five years as a fulfillment of a democratic system. Every citizen is guaranteed the right to vote and be elected in accordance with the 1945 Constitution. However, the reality is that the general election itself raises many issues and political phenomena that bring each other down. For example, the case of papa asking for shares, namely the corruption of electronic ID cards carried out by Setya Novanto until the existence of fake cells caught a lot of public attention because they succeeded in embezzling 258 billion funds (Ramadhania, 2018). In addition, in the 2019 presidential election, which took place with many slanted issues, identity politics, swaying opinions, slander, religious sentiments and group sentiments adorned the implementation of the 2019 presidential election. The heat of political activity during the 2019 presidential election was also followed by increased awareness and political maturity of the youth. millennials in political developments in Indonesia.

According to data (Ardipandanto, 2020) it was written that in the 2019 General Election, anti- establishment identity politics was assessed to have strengthened again when the circulation of narratives carrying the concept of populism such as the "2019 Change President" Movement, "Satan's party vs. do not trust well-established institutions (KPU and $\mathrm{MK}$ ) or independent institutions (quick count, etc.). Not only that, there was the politicization of religion in the 2019 Presidential Election, where the Indonesian political year that took place in 2018-2019 was predicted and watched 
out by various parties regarding the use of ethnic and religious sentiments in political competition. Indonesia should learn a lot from the case of politicization and capitalization of religion that occurred during the election for the governor of DKI Jakarta the previous year(Kurniawan, 2018)

Political maturity (Ketut, 2013) is the maturity or maturity of attitudes and behavior of individuals, groups, and institutions/organizations in dealing with the state, government, power, facts and political activities, as well as in political organization. Political maturity itself contains two perspectives, First, which emerges from itself as an autonomous expression or objective condition of individuals. Second, which arises as a result of (or response to) the environment outside of him. This means that political maturity is needed by all elements of political organizations in carrying out political activities in political organizations

Indonesia itself, which is now in the era of the industrial revolution, makes Indonesia in all aspects of its activities always in contact with technological developments, including politics. Political communication and adult political socialization have now been connected to existing technology, one of which is social media. (Anshari, 2013) wrote that the presence of social media has a role in the political field where a study in the United States shows that social media is an effective campaign tool because the presence of new digital-based media makes political information not only more massive, but also distributed quickly and in a timely manner. interactive.

The link between social media and political communication as a form of political development in Indonesia makes the boundaries between the government and the community increasingly thin considering that the community itself, including youth, can easily channel their aspirations directly as a form of political communication through social media so that on social media there is a relationship. interaction between the government and the people. In addition, many people, especially youth and students, use social media as a lifestyle in their daily life. Youth dependence on smartphones results in the ease of youth in expressing their comments and activities on their social media such as Instagram, line, whatsapp, youtube and many more.

On social media such as instagram, youtube, whatsapp, line, and twitter, they are often active in presenting shows about politics which are much favored by users, especially students. The activeness of social media in its role as political communication and political socialization is an effort that can be made with digital literacy

In interpreting digital literacy, digital literacy in the midst of the development of social media also needs to be balanced by the ability to think creatively because the easier it 
is for social media users to access all news and films, it will have a lot of impact on political knowledge, political rights and political choices. The impact of the easier access to political information on social media on political choices, in reality, it was found that someone who originally made his political choices would in the future be reluctant to use his political rights or abstentions during the general election, especially in the presidential election after seeing impressions on one of the social media. .

Concrete examples of social media have a role in determining a person's political rights when the Sexy Killers film is shown on YouTube social media when approaching the 2019 Presidential election which ultimately has an impact on friction in society. The screening of Sexy Killers, which can be easily accessed on YouTube, makes millennials who access the film understand things that were previously unknown behind the scenes. In short, how are the mine owners who are indifferent to the surrounding environment so that local residents feel very disadvantaged by the PLTU being built in their environment. Sexy Killers . screeningIt creates irony for people who really don't know anything about PLTU, and if you look back at the screening of Sexy Killers, there are influential political figures in each candidate pair 01 and 02 who are increasingly making people rethink their political rights.
If it is linked again between the development of social media and political choices such as the screening of the film Sexy Killers which affects the political rights of the Indonesian people, especially students, the formulation in this study is related to how to analyze the impact of the presentation of Sexy Killers on the Political Rights of Students of the Faculty of Social Sciences and Law at the State University Surabaya with the aim of research to describe the impact of the presentation of Sexy Killers on the Political Rights of Students of the Faculty of Social Sciences and Law at the State University of Surabaya. The benefits of this research on the expected theoretical benefits teoritiscan contribute ideas and increase knowledge or discipline for all parties regarding the analysis of the impact of the presentation of Sexy Killers on the Political Rights of Students of the Faculty of Social Sciences and Law at the State University of Surabaya and the practical benefits in this research are expected to provide insight and be used as a reference on how to analyze the impact Presentation of Sexy Killers Against Political Rights of Students of the Faculty of Social Sciences and Law at the State University of Surabaya

In this study, in analyzing the impacts of the presentation of Sexy Killers on the Political Rights of Students of the Faculty of Social Sciences and Law at the State University of Surabaya using the theoretical basis of Peter L Berger where in viewing a social reality of 
society, there are three interrelated stages namely internalization, objectivation, internalization (Bungin, 2011) . In this study, it is centered on objectivation or knowledge that is built, meaning that the political agency of students of the Faculty of Social Sciences and Law at the State University of Surabaya is much influenced by the knowledge that is built through the screening of the sexy killers film.

\section{RESEARCH METHODS}

This study uses a qualitative approach with a case study research design that refers to Yin's opinion where case studies are research that investigates contemporary real events that are still related to the present, both currently happening, or have been completed but still have an impact that is still felt on the present. during the research (Yin, 2018). The case study research design was chosen considering that during the 2019 presidential election there was the screening of the sexy killers film which had an impact on determining the voting rights of the Indonesian people along with political sentiment and religious sentiment.

The focus of this research is on student suffrage due to the screening of the sexy killers film, and indicators of student suffrage, namely political views related to political knowledge and knowledge of prospective leaders. In addition, in the second indicator there is a student's political attitude related to the choice of giving the right to vote during the election or not giving the right to vote during the 2019 election.

Informants in this study were active students of the Faculty of Social Sciences and Law, State University of Surabaya with minimum criteria of 3 rd semester students, active in campus organizations with the condition that they contribute at least 2 years and are members of off-campus organizations. The location of the research was carried out at the Surabaya State University campus, Jl. Potatoes Surabaya. This research was conducted in June 2019 - July 2019

The data collection technique in this study used in-depth interviews with informants who focused on student suffrage due to the screening of the sexy killers film which was related to (1) political views regarding political knowledge and knowledge of prospective leaders, (2) students' political attitudes regarding the choice of voting rights at the time of the election. election or not granting the right to vote during the 2019 election. In-depth interviews were used because this research focused on student suffrage related to the knowledge that was built. This means that students' voting rights are due to the screening of the sexy killer film everything is in accordance with the knowledge that has been built regarding politics so that it has an impact on the existence of student suffrage rights, still using their voting rights as citizens or even not 
using their voting rights during the 2019 election

The analysis technique in this study uses the Miles and Huberman Interactive Data Analysis Technique which after the student suffrage data is due to the screening of the sexy killer film, then the data will be reduced to data centered on the student suffrage because the sexy killer film is shown to remain in accordance with the research focus, and then the data presented in the form of a narrative related to student voting rights due to the screening of the sexy killer film sexy, whether the right to vote has an impact on the right to vote or not to use the right to vote during the 2019 election, all of which are adjusted to the knowledge that has been built. Furthermore, at the conclusion drawing stage, it will conclude on the choice of using student voting rights during the election or even the choice of voting rights that are not used during the 2019 election. In the data validity technique, triangulation of sources is carried out to obtain credible data by comparing the results of interviews with other references such as journals. and some updates shared on private platforms especially on private instagram and whatsapp platforms.

\section{DISCUSSION}

Student Political Views due to the screening of Sexy Killers

Students of the Faculty of Social Sciences and Law, State University of
Surabaya who became informants in this study with a focus on student suffrage due to the screening of the sexy killers film.where the indicators of political views have welldeveloped political knowledge, conceptually FISH students have been able to build a good political understanding which is always associated with power. Political views that become indicators of student suffrage are important considering that when choosing one candidate in the general election, the basis for that choice is heavily influenced by political views. As according to EM students who are active in campus organizations and outside campuses, if they choose one candidate during the general election, what must be done beforehand is the vision and mission of the candidate. EM itself does not deny that when choosing a candidate it is also based on the track recordthe candidate. This means that in student suffrage, the knowledge that is built on students related to political knowledge can already be well constructed. Good political knowledge is what we are trying to harmonize with knowledge related to candidate candidates where students who are educated individuals will try to find out details regarding their respective candidates to arrive at certainty in choosing during the 2019 general election.

The relationship between political views and the political rights of students because of the sexy killers film shows how EM and SI students view the description of 
the sexy killers film and draw conclusions on the sexy killers film. EM describes the sexy killers film as a black picture that is not known to many parties including himself so that the sexy killers film provides additional references regarding the candidate pairs of candidates where according to EM in the sexy killers film there are two figures from each candidate who have a role in .... so that through the screening of the film sexy killers Knowledge related to the candidates for the 2019 presidential election has increased so that EM explains that there is a view not to choose the two candidates in the 2019 presidential election.

When it is associated with Peter L. Berger's theory, the choice of student political rights due to the screening of sexy killers is influenced by the construction of knowledge that is built. This means that the political rights of students because of the screening of the sexy killers film are heavily influenced by the student's political views on the sexy killers film . Students' political knowledge as well as knowledge related to prospective candidates ultimately builds students' perspectives in seeing each candidate which leads to the determination of student suffrage

\section{Student Political Attitude due to the screening of Sexy Killers}

In the screening of the sexy killer film which has an impact on the political election rights of students, the political attitudes of students become important to be analyzed. SI informants who have seen the movie sexy killerson the youtube platform decided not to cast his vote in the 2019 presidential election. SI said that he did not believe in the two pairs of candidates who turned out to have contributed to the losses suffered by the community.... so SI chose not to vote in the 2019 presidential election. No only SIVB also revealed that the political attitude chosen as a student was to continue to give voting rights in the 2019 presidential election even though when VB saw the sexy killers film, she felt she no longer trusted each candidate but VB chose to keep voting because VB was aware that Humans always have mistakes, so the method used by VB is not only to look at the track record of each candidate but also to analyze the vision and mission of each candidate in the 2019 presidential election.VB also said that in determining the right to vote, students as educated people need to continue to analyze and be critical of each information so that the choice of abstaining is not the main choice.

Political attitude (Ladini, 2016) is the readiness to act, perceive a person or group to deal with, respond to political problems that occur which are expressed in various forms. If the political attitude is positive, then the political behavior shown will also be positive. Conversely, if the political attitude shown is negative, then the political behavior shown is also negative. The positive or 
negative of a political attitude depends on several things, namely the ideology of the actor of the political attitude, the organization that shows the political attitude, the cultures that live in the environment of the actor of the political attitude.

Political attitude itself is certainly shaped by several factors, it can depart from personal experience, the influence of other people who are considered important, the influence of culture, educational and religious institutions, and the mass media. The mass media itself has a role in determining the political attitudes of individuals and society because as a means of communication, various forms of mass media such as television, radio, newspapers, magazines and others have a major influence in the formation of public opinion and trust (Retnawati, Suntoro, \& Nurmalisa, 2015).

When analyzed using Peter L. Berger's theory where a person's political attitude to be able to vote or not to vote in the 2019 presidential election, of course, a lot is influenced by the construction of knowledge that is built, especially in the screening of sexy killers films. This means that students will form knowledge of each candidate for the 2019 presidential election so that knowledge will ultimately shape students' political attitudes in determining their voting rights as students and as citizens in the 2019 presidential election.

\section{CONCLUSION}

Analysis of the impact of the existence of political populism on the political rights of students of the Faculty of Social Sciences and Law, State University of Surabaya through the screening of the short film sexy killers, brings up several distinct impacts on changes in student political views and student suffrage and student political choices. Many of the UNESA FISH students were initially proud of their political choices but instead were disappointed with the reality presented by the screening of the short film sexy killers.. So that many of the students of the Faculty of Social Sciences and Law, State University of Surabaya feel pessimistic about their political choices, even though the steps taken by students are only choosing political candidates who are considered good in terms of achievement and track record of each candidate so that there is no political choice for golput, even though Students of the Faculty of Social Sciences and Law, State University of Surabaya feel pessimistic about the 2019 Presidential candidates

\section{REFERENCES}

[1] Ansari, F. (2013). Political communication in the era of social media. Journal of Communication , 8 (1), 91-101.

[2] Ardipandanto, A. (2020). Impact of Identity Politics in the 2019 Presidential Election: Populism Perspective [The Impact of Identity Politics On President Election 2019: Populism Perspective]. Journal of Politica Dynamics of Domestic Political Problems and International Relations , 11 (1), 43-63. 
[3] Arsad, A., Suaib, E., \& Nasir, M. (nd). CAUSES OF POLITICAL CONFLICT IN THE ELECTION OF VILLAGE HEAD (CASE STUDY IN KANCEBUNGI VILLAGE, MAWASANGKA DISTRICT, CENTRAL BUTON REGENCY). CALGOVS (LOCAL POLITIC AND GOVERNMENT ISSUES) , 1 (02), 3852.

[4] Bungin, BM (2011). Social construction of mass media: the power of influence of mass media, television advertising and consumer decisions and criticism of Peter L. Berger \& Thomas Luckmann . date.

[5] Chusnul Mar'iyah. (2020). Political Conflict: City Life and Building Local Democratic Communities. Symposiumjai.Ui.

[6] Daradji, OKI (2019). Pejambon 1945 The Great Consensus of the Founding Fathers of the Nation.

[7] Halim, W. (2017). Perspective of Social Exchange in Community Political Behavior in Malang City Election 2013. Indonesian Politics: Indonesian Political Science Review , 2 (2), 201-226.

[8] Haryanto, H. (2014). The Rise of Party ID: An Analysis of Voting Behavior in Local Politics in Indonesia. Journal of Social and Political Sciences , 17 (3), 291-308.

[9] Ketut, G. (2013). Building Political Maturity in Facing the 2009 Election. Fisip Unmul.

[10] Kurniawan, B. (2018). The Politicization of Religion in the Political Year: Post-Truth Politics in Indonesia and a Threat to Democracy. Journal of the Sociology of Religion , 12 (1), 133-154.

[11] Ladini, M. (2016). Political Attitudes of Farmers in the 2015 Semarang District Election in Pringapus Village, Pringapus District. Semarang State University.

[12] Nambo, AB, \& Puluhuluwa, MR (2005). Understanding About Some Political Concepts (a Study of Political Systems). LIMBAR: Journal of Social and Development , 21 (2), 262-285.
[13] Noer, D. (1965). An introduction to political thought (Vol. 1). Dwipa.

[14] Ramadhania, U. (2018). THE EFFECT OF REPORTING THE ALLEGED CASE OF SETYA NOVANTO'S E-KTP CORRUPTION IN THE MEDIA ON THE LEVEL OF PUBLIC TRUST IN THE DPR-RI (Study of 2016 FISIP Students, University of Lampung) .

[15] Retnawati, E., Suntoro, I., \& Nurmalisa, Y. (2015). The Influence of Mass Media and Political Attitudes on Students' Political Participation in Elections .

[16] Yin, RK (2018). Case Study: Design \& Methods (; MD Mudzakir, ed.). Depok: Rajawali Press. 